\title{
Developing Model of Quality Assurance for Higher Education Institutes
}

\author{
Darwis \\ Student Doctoral Program of Education University of \\ Bengkulu /Lecturer in Bengkulu Health Polytechnic \\ Bengkulu, Indonesia \\ darwis_poltekkesbkl@yahoo.co.id
}

\author{
Badeni \\ Departement of Education FKIP \\ University of Bengkulu \\ Bengkulu, Indonesia \\ mbmbadeni@gmail.com
}

\author{
Sudarwan Danim \\ Departement of Education FKIP \\ University of Bengkulu \\ Bengkulu, Indonesia \\ dansudarwan@gmail.com \\ Wachidi \\ Departement of Education FKIP \\ University of Bengkulu \\ Bengkulu, Indonesia \\ wachidi@unib.ac.id
}

\begin{abstract}
The main focus of this study is to examine similarity, excellence, and lack of the programs implementation, including ISO 9001:2015, SPMI, SPIP and Accreditation an effort of quality assurance to improve the performance of higher education institutes. Recently, there is no synchronization between auditors including Satuan Pengawas Internal/ Internal Audit Unit (SPI), Audit Mutu Internal (AMI), Audit ISO 9001:2015 and Sistem Akuntabilitas Kinerja Instansi Pemerintah (SAKIP). The purpose of this study is to develop an integrative model of quality assurance in higher education performance which refer to the requirements described in the national standard of higher education (SNPT). The standard of quality assurance covered eight of national education standards, added with standard of education and learning, research standard and standard of community service. This research design was qualitative method that includes a case study in Bengkulu Health Polytechnic. Data were collected by applying the qualitative methods namely observation, interview, and documentation. The data were analyzed using thematic analysis. This research found that there were similarity, excellence and lack of each accreditation program. As an alternative, a new form of quality assurance program, called integrative model of performance was developed in order to enhance the quality of higher education institutes to fulfill the requirements in the national standard of higher education.
\end{abstract}

Keywords-Model of Quality Assurance, National Standard of Higher Education, integrative model of performance enhancement in higher education.

\section{INTRODUCTION}

The presence of a quality assurance in university environment is ideal to maintain quality of ideology and academic. Accreditation system is one of assessment ways to universities in Indonesia. The assessment is used as a benchmark of quality for all study programs and institution of higher education starting from public, private, institutional and religious universities that organize professional and academic programs. Many systems are required to maintain and improve the quality of time that must be done both by government and by outsiders, such as, SPMI, SPME, ISO 9001: 2015, SPIP and SAKIP. Currently, these quality assurance systems still use manual systems in which the overall assessment has been built on supporting data. Quality assurance systems that have not been integrated provide the same goal of continuous quality improvement of universities. When each system is integrated into one system, then the quality assurance activities of higher education will be simpler. The purpose of this study is to develop an integrative quality assurance model in higher education performance that refers to the requirements set forth in the national higher education standard (SNPT).

\section{THEORY}

\subsection{Quality Assurance of Higher Education}

"Quality" means those features of products which meet customer needs and thereby provide customer satisfaction[2]. In 2003 along with the issuance of Law Number 20 Year 2003 on National Education System (UU Sisdiknas), the Directorate General of Higher Education began to implement Quality Assurance of Higher Education gradually. Quality Assurance Higher Education aims to ensure the quality of 
higher education by universities in Indonesia [3]. The Quality Assurance System of Higher Education mandated by Law Number 12 Year 2012, implemented by integrating the three pillars namely, Internal Quality Assurance System implemented by each university; External or Accreditation Quality Assurance System implemented by the Accreditation Board of Higher Education or Independent Accreditation Institution; And Database of Higher Education both at the level of higher education and level of Directorate General of Higher Education. Universities should also try to meet the international quality standards of an educational institution that is by obtaining ISO 9001: 2015 certificate. As a state university under government supervision, the university should also implement the Government Internal Control System (SPIP) as well as the Government Institution Performance Accountability System (SAKIP).

\subsection{ISO $9001: 2015$}

ISO 9001: 2015 aims to ensure the sustainability of a quality management system and has a focus area on an organization's management system. This International Standard uses a process approach, incorporating the Plan-DoCheck-Act (PDCA) cycle and risk-based thinking. The PDCA cycle can be applied to all processes and to the quality management system as a whole. In order to comply with the requirements of this International Standard, an organization needs to plan and implement actions to address risks and opportunities. Dealing with risks and opportunities makes a basis for improving the effectiveness of the quality management system, achieving better results and preventing negative impacts. The adoption of a quality management system is a strategic decision for an organization that can help to improve its overall performance and provide a sound basis for sustainable development initiatives. The potential benefits to an organization of implementing a quality management system based on this International Standard are [4]:

a. The ability to consistently provide products and services that meet customer and applicable statutory and regulatory requirements;

b. facilitating opportunities to enhance customer satisfaction;

c. addressing risks and opportunities associated with its context and objectives;

d. the ability to demonstrate conformity to specified quality management system requirements.
Consistently meeting requirements and addressing future needs and expectations poses a challenge for organizations in an increasingly dynamic and complex environment. To achieve this objective, the organization might find that it is necessary to adopt various forms of improvement in addition to correction and continual improvement, such as breakthrough change, innovation and re-organization[4].

ISO 9001 is a standard that sets out the requirements for a quality management system. It helps businesses and organizations to be more efficient and improve customer satisfaction. A new version of the standard, ISO 9001:2015, has just been launched, replacing the previous version (ISO 9001:2008). ISO standards are reviewed every five years and revised if needed. This helps ensure they remain useful tools for the marketplace. The challenges faced by business and organizations today are very different from a few decades ago and ISO 9001 has been updated to take this new environment into account. [5].

The most noticeable change to the standard is its new structure. ISO 9001:2015 now follows the same overall structure as other ISO management system standards (known as the High-Level Structure), making it easier for anyone using multiple management systems. Another major difference is the focus on risk-based think- ing. While this has always been part of the standard, the new version gives it increased prominence. The new version of the standard brings the user a number of benefits. For example, ISO 9001:2015 [5]:

a. Puts greater emphasis on leadership engagement

b. Helps address organizational risks and opportunities in a structured manner

c. Uses simplified language and a common structure and terms, which are particularly helpful to organizations using multi- ple management systems, such as those for the environment, health \& safety, or business continuity

d. Addresses supply chain management more effectively

e. Is more user-friendly for service and knowledge-based organizations

To obtain an ISO 9001: 2015 certificate, an audit by an international certification body must be performed. The acquisition of ISO 9001: 2015 certificate will have good impact for the organization especially the continuous improvement in the management system so as to produce better products as well. The ISO system also has disadvantages, which are related to time and cost. In implementing and running the ISO system is quite expensive, 
such as preparing standard operating procedures that must bring in an outside consultant. To maintain the ISO certificate must also be carried out regular audits that cost considerable. ISO 9001: 2015 audit activities should be done every 6 months to maintain the quality management system. Not only cost, but also takes time to prepare everything according to the standards to get ISO certification. Despite its drawbacks, ISO 9001: 2015 has several benefits that greatly impact an institution. If a university can maximize the quality assurance system according to ISO standards, it will increase the productivity of higher education and product quality.

\subsection{Internal Quality Assurance System (SPMI) [6]}

SPMI is a systemic activity of quality assurance of higher education developed by each university autonomously or independently to control and improve the implementation of higher education on a planned and sustainable basis. Each university can develop its own SPMI, among others in accordance with historical background, the basic values that animate the establishment of the college, the number of study programs and human resources, facilities and infrastructure of the college without the intervention of others. SPMI aims to control and improve the quality of higher education that is planned and sustainable. SPMI activities conducted by each College through Internal Quality Audit conducted every 6 months and produce output in the form of internal audit reports.

This goal can only be achieved if every university has implemented SPMI properly and correctly. The function of SPMI is as:

a. Part of the effort to improve the quality of higher education;

b. Systems for realizing the vision and carrying out the college mission;

c. Means to obtain accredited status and accredited rating of study programs and universities; and

d. Systems to meet the needs of college stakeholders.

In Article 52 paragraph [2] of the Higher Education Law, it is stated that quality assurance is conducted through 5 (five) main steps which are abbreviated as PPEPP, namely the Determination, Implementation, Evaluation, Control and Improvement of Standard of Higher Education. These five major steps must exist in implementing the SPMI, even the most important thing of SPMI in every college. The five main steps in the SPMI of a university are closely related to the standards in the SPMI. The standard that should be used in the SPMI of every university is the SN Dikti set by the Education and Education Standards set by each university with reference to SN Dikti. SN Dikti is a standard unit which includes National Education Standards plus National Standard for Research, and National Standards of Community Service. Meanwhile, the Higher Education Standard set by each university comprises a number of standards in the academic and non-academic fields which extends beyond SN Dikti.

The core of SPMI is the existence of the Standard of Higher Education which serves as a benchmark for assessing the quality of the organization of higher education. Thus, the implementation of SPMI in universities will cause universities to work based on the established Standard of Higher Education. All of these Dikti standards must be pursued by the leaders, lecturers, education personnel, and students. There are some advantages SPMI implementation by universities that is, able to identify the strengths and weaknesses of the college as the basis for making the development plan of universities. SPMI conducted by each university also has weaknesses in its implementation related to the concept, instrument, infrastructure, administration and human resources. In the implementation of SPMI, often found an audit result that does not match the fact so that the assessment on the quality of college is not bad.

\subsection{External Quality Assurance System (SPME) (6)}

The accreditation of the study program is an assessment activity to determine the feasibility of the study program, while the accreditation of the college is the assessment activity to determine the eligibility of the college. SPME or accreditation is one of the subsystems of SPM Dikti in addition to two other subsystems, each called SPMI subsystem and PD DIKTI subsystem. The accreditation of universities is carried out by BAN-PT, while the accreditation of the study program is carried out by LAM. Universities may also apply for accreditation to international institutions such as ABET for technical science. SPME or accreditation is done through an assessment of the application of SPMI by universities to establish accredited status and accredited rating of study program and /or university.

The National Accreditation Board of Higher Education (BAN-PT) develops the National Accreditation System of Higher Education (SAN Dikti), which is a unity of external higher education quality assurance policy framework applicable in the jurisdiction of the Unitary State of the Republic of Indonesia. SAN Dikti is intended to encourage internal initiatives and responsibilities of unit managers of 
study programs and higher education institutions to conduct continuous quality improvement. At the time of the permit for the implementation of the study program and the permit for the establishment of a university is published by Mendikbud, the study program and the college obtain accredited status and a minimum accredited or well accredited rating.

The problem that arises is how to organize the entire data of the study program spread and irregular well so that it is easier to be evaluated by itself before the evaluation period by national accreditation institution or National Accreditation Board of Higher Education [7]. According to Article 6 of Regulation of the Minister of Research, Tenologi, and Higher Education Number 62 Year 2016 on Quality Assurance System of Higher Education, SPME conducted through accreditation has an activity cycle consisting of:

1. Data and Information Evaluation Phase;

2. Determination of Accreditation Status and Accredited Ranking; and

3. Stage of Monitoring and Evaluation of Accreditation Status and Accredited Ranking.

SPME is performed every 4 years and after accreditation by BAN-PT or LAM-PT, a certificate that shows the audit result of yeng consists of $\mathrm{A}, \mathrm{B}, \mathrm{C}$ and not accredited. The weaknesses of SPME are related to the considerable cost that each activity will incur, but the weakness will be replaced by the continuous improvement of the quality of the university.

\subsection{Government Internal Control System (SPIP)}

SPIP is a system of controls that are held thoroughly in the central and local government [8]. Implementation of SPIP implementation in every work unit within the Ministry of Health, is expected to encourage all work units to implement all policies/programs established by the Minister of Health that leads to the achievement of the goals and objectives of the organization. The implementation of SPIP in the work unit is carried out through the enforcement of integrity and ethical values, commitment to competence, conducive leadership, organizational structure formation as needed, delegation of authority on human resources development, the realization of effective internal government supervision role and good working relationship with government [9].

SPIP aims to provide reasonable assurance for the achievement of effectiveness and efficiency in achieving the objectives of state governance, reliability of financial reporting, asset security, and compliance with laws and regulations [8]. SPIP controls activities that are potentially risky and can hamper in achieving organizational goals undertaken by agency heads. Implementation of SPIP implemented together and become an integral part and activity of government agencies and consists of:

1. Control environment

2. Risk mapping, risk analysis, risk impact, and risk control

3. Control activities

4. Information and communication

5. Monitoring of internal control

SPIP audit activities can be done in accordance with the policies of each agency. Implemented by SPIP is expected to grow awareness of all staffs of the importance of SPIP and each work unit has SPIP document according to task field/ activity ranging from risk statement to action plan of control, so that it can have an impact on the institution that is governance of government institution/bureaucracy clean, Quality, free from corruption, trusted user community (integrity zone). SPIP requires commitment from all fronts to staff. Weakness of SPIP if human resources at university do not have a strong commitment. Weak commitment can be due to human resources are not reliable or do not have sensitivity to risk or the creation of conflict of interest.

\subsection{Performance Accountability System of Government Institutions (SAKIP)[10]}

The Government Institution's Performance Accountability System (SAKIP) is a systematic set of activities, tools, and procedures designed for the purpose of establishing and measuring, data collecting, classifying, summarizing and reporting performance on government institution, in order to be responsible and to improve the performance of government institution. Outcome of SAKIP is a Performance Accountability Report of Government Institution (LAKIP). LAKIP is a means to convey the performance responsibility of government institution. LAKIP is reported annually that focuses on institution performance results. For a head of government institution, SAKIP will be very useful to measure every performance that has been implementedby its institution as well as a measure of accountability of the state budget that has been used.

Government agencies compiled an overview of evaluation results on the implementation of SAKIP in their environment and subsequently submitted to the Ministry of PAN RB. Ministry of Administrative Reform and Bureaucratic Reform (Ministry of PAN RB) conducts an evaluation on the implementation of SAKIP ministries/ Institutions / Provincial / District /City Government. In conducting the evaluation, the 
Ministry of PAN RB can be assisted by the Financial and Development Supervisory Board (BPKP). LAKIP evaluation results include 5 components namely, performance planning, performance measurement, presentation of performance information, performance evaluation and performance achievement. The highest score of LAKIP evaluation is AA (satisfactory) with score 85-100, A (very good) score 75-85, CC (good enough) with score 50-65, C (less good) with score 30-50, D (less) with a score of 0-30.

\section{METHODS}

This research design was qualitative method that includes a case study in Bengkulu Health Polytechnic. Data were collected by applying the qualitative methods in the form of observation, interview, and documentation. The data were analyzed based on thematic analysis.

The case studied in this research is about quality assurance model in health polytechnic of ministry of health bengkulu. the steps that will be taken in this research are as follow: 1) conducting data collection, this research is done up to the saturation level of data, and during that also done categorization in themes to find thematic conception about model of quality assurance in health polytechnic of ministry of health bengkulu, 2) make observations, the goal is to obtain findings of propositions on quality assurance model at the health ministry of poltekkes bengkulu. based on the findings in the form of propositions, further analysis and development towards the conceptual to get an abstraction about the quality assurance model at the college of poltekkes ministry of health bengkulu

\section{FINDING}

\begin{tabular}{|c|c|c|c|c|c|}
\hline & ISO 9001:2015 & SPMI & SPME & SPIP & SAKIP \\
\hline Focus area & Management & Management & Management & $\begin{array}{l}\text { Controlling } \\
\text { activities that are } \\
\text { potentially risky and } \\
\text { can be hindered in } \\
\text { achieving } \\
\text { organizational goals }\end{array}$ & $\begin{array}{l}\text { Performance- } \\
\text { Based } \\
\text { Management }\end{array}$ \\
\hline Auditing Agency & $\begin{array}{l}\text { International } \\
\text { Accreditation } \\
\text { Agency }\end{array}$ & $\begin{array}{l}\text { PT Through Internal } \\
\text { Quality Audit }\end{array}$ & $\begin{array}{l}\text { BAN -PT and } \\
\text { LAM- PT }\end{array}$ & $\begin{array}{l}\text { Leaders of } \\
\text { government } \\
\text { institution }\end{array}$ & $\begin{array}{l}\text { Health } \\
\text { Ministry }\end{array}$ \\
\hline \multirow[t]{4}{*}{ Karakteristik } & & & & $\begin{array}{l}\text { The SPIP } \\
\text { implementation } \\
\text { consists of: }\end{array}$ & \\
\hline & & & & $\begin{array}{l}\text { 1. Control } \\
\text { environment }\end{array}$ & \\
\hline & & & & $\begin{array}{l}\text { 4. 4. Information } \\
\text { and } \\
\text { communication }\end{array}$ & \\
\hline & & & & 5. Monitoring of & \\
\hline
\end{tabular}




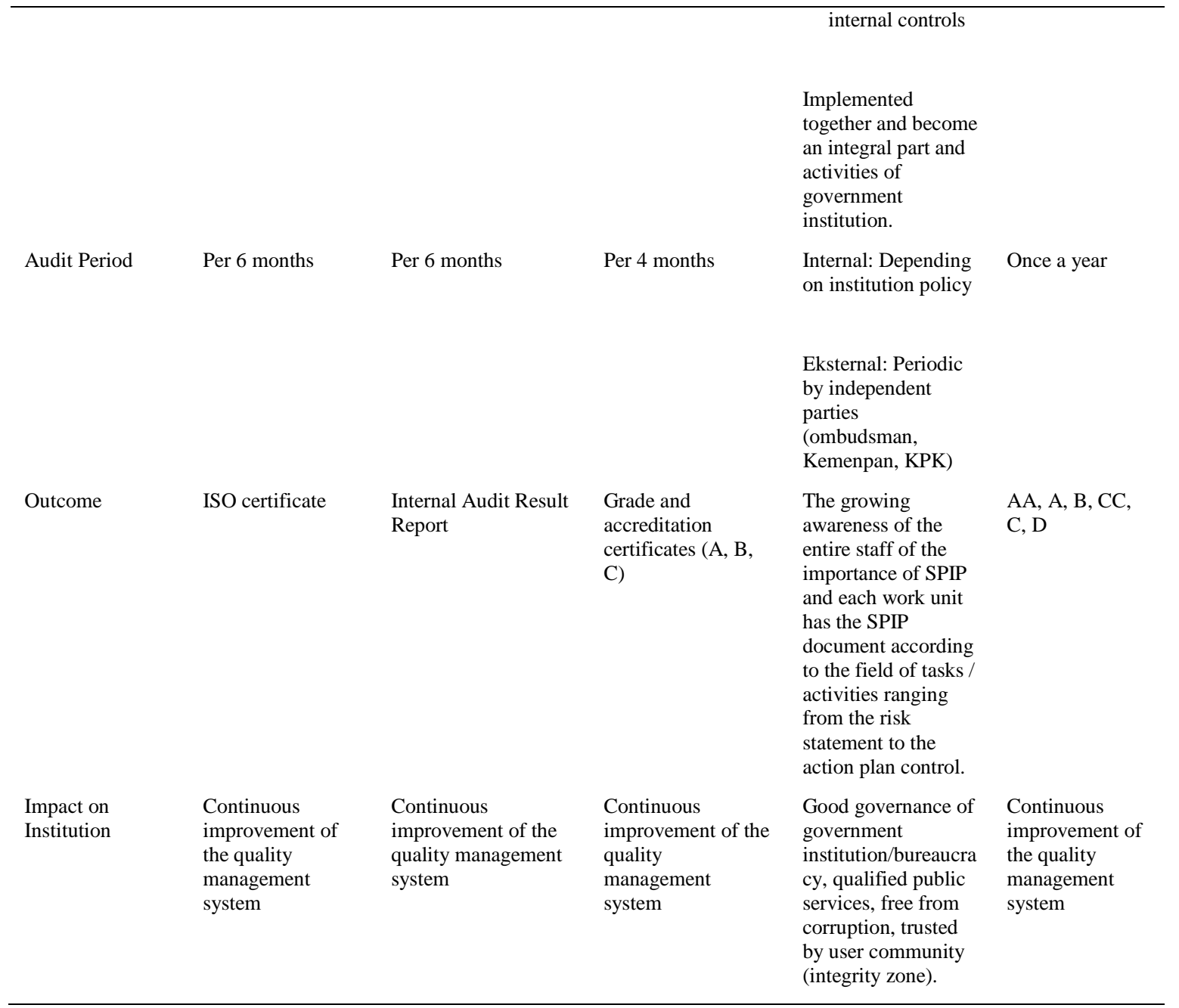

\begin{abstract}
V. DISCUSSION
Synchronization of SPMI, SPME, ISO 9001: 2015, SPIP and SAKIP should be done to improve the quality of higher education to the maximum level. Increasing the number of universities in Indonesia should be accompanied by improvements in the quality of education so that the graduates produced will have better quality. Through SPMI and SPME which is a quality assurance system of Higher Education that is required by the government is expected to convince stakeholders that a Higher Education has met or exceeded the Standards of Higher Education set by the government.
\end{abstract}

SPMI implemented by each university and SPME implemented by BAN-PT or LAM-PT is expected to go hand in hand as an effort to encourage Universities to improve the quality continuously (continuous quality

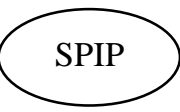

improvement). ISO 9001: 2015 through the Plan-Do-CheckAct (PDCA) cycle and risk-based thinking also has a goal to be synchronized with SPMI and SPME that is to improve the sustainable quality management system. Improving quality management will have an impact on the growth the performance of universities. The increase of institution performance can be seen tie LAKIP delivered every year. To maximize the results of SPMI, SPME, and ISO 9001: 2015 SPIP is required as a potential risk controller and hampers college attainment.

Based on the investigation of some quality assurance above, it can be concluded in chart of Internal and External below 
Internal

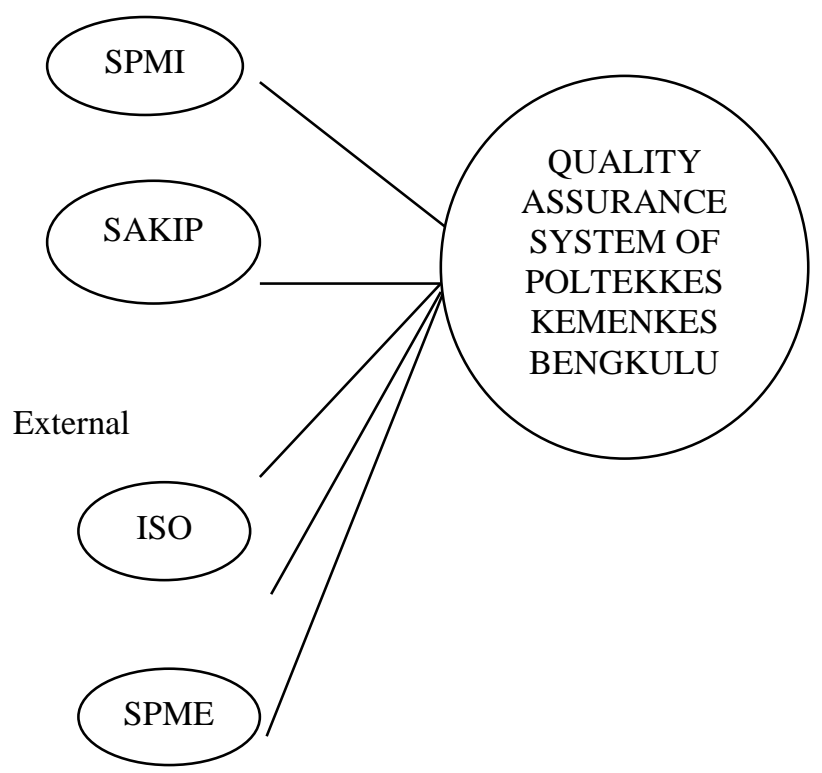

\section{CONCLUSION}

SPMI, SPME, ISO 9001: 2015, SPIP and SAKIP are systems that can be integrated because they share the same end. The synchronization of those systems will facilitate continuous monitoring and quality improvement in a university.

\section{ACKNOWLEDGMENT}

The authors would like to thank Pudir 1, Pudir 2, Pudir 3, Kasubag ADAK, Head of ADUM, Ka SPI, Quality Assurance Unit of Poltekkes Ministry of Health of
Bengkulu and Ibu Tanti (ISO Consultant from PT GIQ) and Mr. Fredinan Yulianda (Quality Assurance Office of IPB) Who has given support in making this paper.

\section{REFERENCES}

[1]. Saputro FC, Anggraeni W, Mukhlason A. Pembuatan Dashboard Berbasis Web Sebagai Sarana Evaluasi Diri Berkala Untuk Persiapan Penilaian Akreditasi Berdasarkan Standar Badan Akreditasi Nasional Perguruan Tinggi. J Tek ITS [Internet]. 2012;1(1):A397-402. Available from: http://ejurnal2.its.ac.id/index.php/teknik/article/view/1141

[2]. Juran JM, Godfrey AB. Juran's Quality Handbook. 5th ed. New York: Mc Graw-Hill Companies; 1999.

[3]. Kementerian Pendidikan dan Kebudayaan. Sistem Penjaminan Mutu Pendidikan Tinggi Sistem Penjaminan Mutu Pendidikan Tinggi. Jakarta; 2014. 1-65 p.

[4]. Cognoscenti Consulting Group. Standar Internasional ISO 9001 : 2015 Sistem Manajemen Mutu - Persyaratan. 2015.

[5]. International Organization for Standardization. Iso 9001 [Internet]. Geneva, Switzerland; 2015. Available from: iso.org

[6]. Kementerian Riset Teknologi dan Pendidikan Tinggi. Pedoman Sistem Penjaminan Mutu Pendidikan Tinggi. Jakarta; 2016. 1-96 p.

[7]. Badan Akreditasi Nasional Perguruan Tinggi. Buku II Standar dan Prosedur Akreditasi Program Studi Sarjana. BAN-PT. Jakarta; 2009.

[8]. Kastowo M. Membangun SPIP: Mencari Model Implementasi Komprehensif. 2008;1-14.

[9]. Kementerian Kesehatan RI. Laporan Kegiatan Persiapan Pemetaan SPIP Inspektorat Jenderal Kemenkes RI. Jakarta; 2011.

[10]. Menteri Pendayagunaan Aparatur Negara Dan Reformasi Birokrasi. Peraturan Menteri Pendayagunaan Aparatur Negara Dan Reformasi Birokrasi Republik Indonesia Nomor 12 Tahun 2015 Tentang Pedoman Evaluasi Atas Implementasi Sistem Akuntabilitas Kinerja Instansi Pemerintah. 2015. 